\title{
Radical right-wing parties in Europe
}

\section{What's populism got to do with it?}

\author{
Jens Rydgren \\ Stockholm University
}

In this paper I discuss, critically, the literature on populism and the extent to which it applies to the contemporary radical right-wing parties in Europe. These parties are often - and increasingly - referred to as populist parties. I argue that it is misleading to label these parties 'populist parties', since populism is not the most pertinent feature of this party family. These parties are mainly defined by ethnic nationalism, and not a populist ideology. In their discourse they are primarily preoccupied with questions pertaining to national identity and national security - and their 'negative' doubles immigration, multiculturalism, Islamist threat - and they consistently pit 'the people' mainly against elites that they view as responsible for a cultural and political threat against their idealized image of their nation state. The ethnic nationalism of European radical right-wing parties is more important for their discourse and tends to influence the populist elements.

Keywords: ethnic nationalism, populism, radical right, party politics, xenophobia

\section{Introduction}

Since the 1980s radical right-wing parties have emerged and become established in a large number of European countries, where parties such as the Front National (France), the FPÖ (Austria), and the Danish People's Party (Denmark), among many others, have received large and enduring electoral support. These parties are united by their ethnic nationalism. Their overall policy objective is to safeguard the nation's majority culture and to keep the nation as ethnically homogenous as possible (Rydgren 2007). Their ethnic nationalism is followed by an exclusionary attitude towards immigrants and - to varying degrees - towards other ethnic or racial minorities, often manifested in xenophobia and sometimes racism. The radical right-wing parties' political messages have been heavily dominated by the 
immigration and refugee issue, especially in Western Europe but in recent years increasingly in Eastern Europe as well (Rydgren 2017; Bustikova 2017). It is also the refugee and immigration issue that primarily attracts voters to these parties: the most distinguishing feature of the radical right-wing parties' voters is that they want to restrict immigration to their country (Arzheimer 2017). If we look more specifically at the message that attracts voters to radical right-wing parties, we see that the link between immigration and supposed crime and other types of social unrest has played a particularly significant role (Rydgren 2008). In addition, immigrants from Muslim countries in the Middle East and Africa are identified as especially problematic and unwelcome by the radical right-wing parties, even though they aim to exclude other groups too (Kallis 2017).

The European radical right-wing parties are often - and increasingly - referred to as populist parties. For example, in a recent volume edited by Kriesi and Pappas (2015) on "European populism," almost all parties discussed throughout the 16 case-based chapters belong to the family of radical right-wing parties. I am critical of this practice for various reasons. As mentioned above, these parties are mainly defined by ethnic nationalism, and not a populist ideology. Ethnic nationalism also largely influences the radical right-wing parties' populist message: these parties' anti-elitist message - directed against an alleged political-correctness elite - emanates primarily from the idea that an elite of established parties, media, and intellectuals have betrayed their country by embracing multicultural and internationalist ideas - and, often, for selling out their country's sovereignty to the EU. This is also reflected at the voter level, where we generally see that political distrust is a less important factor than attitudes toward immigration to explain why voters vote for these parties (e.g., Arzheimer 2017).

Hence, in my view it is misleading to label these parties 'populist parties' since populism is not the most pertinent feature of this party family. A good definition should be both inclusive and exclusive, and it should be based on pertinent qualities of the category being defined. While I see the value of studying and theorizing populism as a phenomenon in its own right, that is, as a feature or dimension of politics that may be more or less manifest in the practices and programs of various political parties - across the ideological spectrum - I am critical of making a priori claims that populism is a befitting label for radical right-wing parties. Moreover, as we will see below, the various definitions of populism being offered by previous literature tend to have problems with demarcation. Some are too general and inclusive, encompassing all parties that make political claims in the name of the people, and that put themselves in opposition to elites; others are too detailed and tailored to fit radical right-wing parties (implying that they are less useful for understanding populism outside of radical right-wing parties). 
The purpose of this paper is to discuss, critically, the literature on populism and the extent to which it applies to the contemporary radical right-wing parties in Europe. My main arguments are, first, that there is a considerable overlap between what is presented as defining features of populism and features of other ideologies such as nationalism and conservatism; and, second, that it may be relevant to use the terms populism or populist in a more restrictive way, as a conditional qualifier (e.g., the ethnic nationalism of European radical right-wing parties tends to be populist in contrast to elitist), while emphasizing that other features of the radical right-wing parties are more relevant and important.

\section{Defining populism: Populism as thick ideology}

In previous literature researchers have used - broadly speaking - three different approaches when defining what populism is: populism as a broad (thick) ideology; populism as a thin ideology; and populism as discourse (or style). While these approaches are not mutually exclusive, they provide a useful way of structuring the literature on the concept of populism.

Let us start with the first. In this tradition, researchers have tried to capture the multi-featured complexity of populism, resulting in a rather long list of defining properties (see Rydgren 2003 for further discussion). Although this may be better described as a description rather than a definition, it helps us close in on the phenomenon.

According to this literature, populist ideology stresses the idea of a harmonious and homogenous people, which also implies nostalgia and reliance on the conception of a 'sacred heartland.' Populist ideology is fundamentally nostalgic and directed toward the past (Berlin et al. 1968, 173-178; Taggart 2000, 16-17; Wiles $1969,170)$. Populist movements generally dislike the present world in which, they argue, people are uprooted and alienated, and they long for a return to the 'rootedness' of an integrated and coherent 'community of the people' (Gemeinschaft) (Berlin et al. 1968, 173-178; MacRae 1969, 156; Taggart 2000, 16-17; Wiles $1969,170)$. Every ideology has utopian aspects, that is, an image of the ideal society, and for the populists this utopia is an idealized past (MacRae 1969, 162).

This trait is inherently bound up with populists' urge to speak in the name of 'the people.' Simultaneously, they present a dualism by pitting 'the people' against 'the elite.' They argue that the political elite, including established political parties, is corrupt and out of tune with the wishes of the people, and that a new movement, which springs directly from the people, and which "will set aside both doctrine and selfish interest and put the people first" (Canovan 1981, 262), is needed. 
As a result, populists distrust most formal social institutions: political parties, bureaucratic institutions of the state, the universities, the media, and the financial institutions. This attitude is a result of their opposition to elites and elite values (Canovan 1999, 3). In populist ideology and rhetoric, the elites, especially those peopling political and cultural institutions, are seen as not only corrupt but also lacking in wisdom, which resides only in 'the people' (Shils 1956, 101-103; Taggart 2000, 11).

In populist ideology and rhetoric 'the people' is presented as monolithic, as a unitary entity without internal divisions (Taggart 2000, 92). Still, in order to treat 'the people' as monolithic, populists exclude whole groups of individuals. Exactly what groups are excluded varies from one movement to another. However, they often involve the 'elites', immigrants, and other ethnic minorities, and sometimes internationalists and supranationalists (Canovan 1999, 5). As will be further discussed below, populism thus often overlaps with ethnic nationalism. Populists have a tendency to equate 'the people' with 'the nation' and, in a manner similar to ethnic nationalists, stress the eternal value of 'organic community' (e.g., Mény and Surel 2000, 217-218; Stewart 1969, 183).

Taggart (2000) has used the term 'heartland' as a way of conceptualizing the populists' lines of inclusion. According to Taggart (2000, 3, 95), populist ideology tends to build on an idealized image of a chosen people that is located in a similarly idealized landscape, that is, a 'heartland.' For some populist movements, the heartland coincides with a nation, for others with a region. However, both these variants are constructed by looking inward and backward; what is imagined is the homogeneous and genuine way of life of an idealized past (MacRae 1969, 155-156). The people inhabiting this imagined heartland constitute 'the people' of populist ideology and rhetoric; those who did not belong to the people of the heartland of the past do not belong to 'the people' of today, either.

Another aspect of the monolithic conception of 'the people,' propagated by populists, is the effort to present it as above class, as classless. Since 'the people' is unitary and undifferentiated by class cleavage, the populists' claim to be 'the voice of the people' must be, as well (Taggart 2000, 96). Hence, we seldom hear populists appeal to the 'working man' or the 'middle classes', but rather to the 'little man, the 'ordinary man', or, mostly, simply to 'the people' (see Worsley 1969, 241).

Populism opposes centralization, division of labor, classes, large-scale production, and politics that stress the supremacy of economic growth (see Fryklund and Peterson 1981). It furthermore opposes the internationalization of the economy, which they set against the 'real economy' (Mény and Surel 2000, 217-218). There are several reasons for this rejection: because they ruin the community of the people and thus alienate people from their integrated lives and personalities; because they are associated with the 'elites', which by definition are against the 'little people' 
of the 'heartland.' Instead, populism seeks economic policy based on a traditional economy that emphasizes small-scale production, an economy based on family capitalism and craft and trade guilds (Fryklund and Peterson 1981; Mény and Surel 2000, 199). Populist ideology is not against economic inequality per se; only against inequality caused by institutions it does not like. On the other hand, inequality produced by the 'traditional' institutions of the Gemeinschaft is accepted and seen as 'natural' (Wiles 1969, 170).

In extolling the straightforwardness, simplicity, clarity, and common sense of 'the common man', populism aims at a politics of simplicity. Politics should be as simple and direct as the spirit of 'the people,' and solutions to political problems should be formulated in a way that is commonly understood (Taggart 2000, 97, 112). In fact, populists maintain that most political issues actually are much simpler than the political elite pretends. If 'the political class' argues that politics is a complex and difficult task, it is because they want, as Canovan $(1981,208)$ puts it, to "protect the mysteries of their trade from the public gaze." By wrapping up their language in "a fog of complexities and technicalities" (Canovan 1981, 208), they hope to keep the people at a distance, so that they can keep the power by themselves.

By contrast, populists claim that they are in favor of transparent decision making procedures, such as referenda, as well as of simplistically formulated policy proposals. All nontransparent aspects of the political process, such as compromises, coalition building, secret treaties, the technical language of specialists, and so on, are denounced by populist ideology and rhetoric (see Canovan 1999, 6). In addition, populists use the existence of nontransparent political procedures to verify the plausibility of their conspiracy theories.

Conspiracy theories in their modern forms are described by Popper $(1971,95)$ as "a typical result of the secularization of a religious superstition." Such a theory declares, according to Popper $(1971,95)$, that "whatever happens in society - especially events such as war, unemployment, poverty, shortages - is the result of direct design by some powerful individuals and groups." Furthermore, as Lipset and Raab $(1970,15)$ have argued, it "is an essential element of the conspiracy theory that such conspiracy is the decisive factor in turning history." Conspiracy consists of "the manipulation of the many by the few" (Lipset and Raab 1970, 15). Because 'the people' is seen as inherently good - a thought that constitutes the backbone of populist ideology - 'ordinary people' cannot be blamed for the evil and decadence of contemporary society. Instead, this blame is put on 'the elites', and in particular on the secret elites that are working behind the scenes (see, e.g., Müller 2016, 32).

Many of the traits outlined here as defining features of populism also characterize the contemporary radical right-wing parties in Europe. They invoke a heartland' consisting of an idealized past of ethnically homogenous nation states. This, however, is because they are ethnic nationalists and, in addition, it is also a feature 
of their reactionary conservatism (which may potentially be turned into reactionary radicalism), which in turn is part of what defines these parties as radical rightwing. Moreover, these parties present 'the people' in a monolithic way, and they tend to dislike cleavages and division lines within the people. This is presented as a key feature of populism; however, it is also a common feature of traditional conservatism (Rydgren 2003). In order to construct the inherently good 'people' radical right-wing parties tend to exclude large segments of society. This is done on ethnic nationalist grounds, by excluding immigrants and - to varying degrees - other ethnic minorities from 'the people, but also in a populist way by excluding 'the political-correctness elite,' that is, political and cultural elites that not agree with the program of the radical right. In addition, 'traitors' may be excluded, that is, those popular segments that embrace multiculturalist or internationalist attitudes, these people being viewed as having been duped by the political-correctness elite. As noted by Bar-On (2017), to "advance a liberal multicultural perspective is to be [seen as] a 'traitor' to one's people." Hence, although radical right-wing parties put themselves in opposition to elites in general, comprising not only political but also cultural and educational elites, its main enemy is cosmopolitan liberalism and the sociocultural left, which are seen as betraying the nation and corrupting the 'natural' organic order and values within a society (Rydgren 2017). In that way, the radical right-wing parties are anti-pluralists: they treat cleavages as well as opposition to their own political program as illegitimate. This, however, is what defines them as radical right-wing parties. These parties thus mobilize against the elites, a feature of a populist ideology discussed above. And they may be populists in that way. However, we should remember that most new political contenders mobilize, at least in their rhetoric, against the established political elite. That is the natural way to claim that a new contender is needed. Conspiracy theories, in the meaning given to them by Popper and Lipset and Raab above, are often part of radical rightwing parties' discourse. This, however, is mainly because these parties build on a monist or anti-pluralist ideology (Lipset and Raab 1970, 13). Finally, the radical right-wing parties often present their political program in a simplistic and popular way, but so do - to be fair - most political parties in our medialized world, and this does not in itself distinguish radical right-wing parties from other parties. Yet, radical right-wing parties tend to plunge deeper into 'post-truth politics.'

1. From the discussion above we also find some traits that do not generally characterize the contemporary radical right-wing parties in Europe. For example, they tend to mobilize primarily against political and cultural elites, and not so much against economic elites (unless these are bound up with political-economic institutions). 


\section{Populism as thin ideology}

According to Mudde and Kaltwasser $(2017,6)$, populism does not qualify as a full ideology, because unlike "'thick-centered' or 'full' ideologies (e.g., fascism, liberalism, socialism), thin-centered ideologies such as populism have a restricted morphology, which necessarily appears attached to - and sometimes is even assimilated into - other ideologies." More specifically, populism is defined "as a thin-centred ideology that considers society to be ultimately separated into two homogeneous and antagonistic groups, 'the pure people' and 'the corrupt elite,' and which argues that politics should be an expression of the volonté genèrale (general will) of the people." (Mudde and Kaltwasser 2012, 8).

This view, that populism is always mixed up with a 'host ideology' (such as nationalism) makes intuitive sense when trying to understand contemporary radical right-wing parties in Europe. At the same time, however, it begs the question why we should then focus on populism, being a minor part of these parties' ideology, rather than on the 'host' ideologies. There is a risk that researchers, in their more concrete empirical work, end up mistaking features of the host ideology for features of populism (Moffitt 2016, 19). One may also ask whether Mudde and Kaltwasser's definition may not be too minimal and, more importantly, too general and inclusive.

In his recent book on populism, Müller (2016) provides a less inclusive definition. For Müller, populism is not defined foremost by appealing to 'the people.' The reason is that it is too inclusive a criterion: "After all, every politician - especially in poll-driven democracies - wants to appeal to 'the people;' all want to tell a story that can be understood by as many citizens as possible, all want to be sensitive to how 'ordinary folks' think and, in particular, feel" (Müller 2016, 2). Neither is it a sufficient condition to be "critical of elites in order to count as a populist" (Müller 2016, 2). In addition, we must add anti-pluralism: "Populists claim that they, and they alone, represent the people" (Müller 2016, 3).

Hence, for Müller populism consists of two key features, anti-elitism and anti-pluralism. First, Müller $(2016,19)$ views populism as "a particular moralistic imagination of politics, a way of perceiving the political world that sets a morally pure and fully unified - but ... ultimately fictional - people against elites who are deemed corrupt or in some other way morally inferior." Yet, populists are not inherently anti-elitists, since they "have no problem with representation as long as they are the representatives; similarly, they are fine with elites as long as they are the elites leading the people" (Müller 2016, 29). Second, Müller $(2016,20)$ argues that populists always claim "that they, and only they, represent the people." All political competitors are seen by the populists as being part of "the immoral, corrupt elite." In a related way, populists tend to view all opposition as illegitimate and, 
indeed, to exclude those who disagree with them from "the proper people," which is always "defined as righteous and morally pure," by branding them as "enemies of the people" (Müller 2016, 20; 3).

This is the reason why populism, according to Müller $(2016,3)$, tends to "pose a danger to democracy," which "requires pluralism." Based on a pars pro toto argument, populists claim that they, and they alone, represent the people as a whole (Müller 2016, 20), making political debates and parliamentary deliberations inherently meaningless. Hence, for "a political actor or movement to be populist, it must claim that a part of the people is the people - and that only the populist authentically identifies and represents this real or true people" (Müller 2016, 22-23). The people is constructed as inherently good, and populists depend on different criteria for distinguishing those that belong to the 'real' morally pure people. Such criteria can be based on conceptions of corruption, on productivity, and often on ethnic and racial markers (Müller 2016, 24-25).

Müller's description of populism captures well the features of the radical rightwing parties in Europe. They are clearly anti-pluralist (but again, so is all political extremism, ${ }^{2}$ not the least the right-wing varieties), tend to view 'the people' as morally good, and to exclude oppositional segments of the people, often by branding them traitors. Yet, maybe it fits too well; it reads more like a (partial) definition of radical right-wing parties than of populism generally.

\section{Populism as discourse or style}

Finally, one increasingly prominent strand in the literature has viewed populism as discourse or style - as a particular mode of political expression - rather than an ideology (Moffitt 2016, 21). The key feature of a populist discourse is that a political actor pits 'the people' against 'the elite' (Hawkins 2009). As a result, populism is seen as a variable - a political actor can be more or less populist - rather than a binary opposition between populist and non-populist ideologies (Moffitt 2016, 21).

This perspective has several advantages, not the least being that it is dynamic and open to changes over time. Do the contemporary radical right-wing parties in Europe employ a populist discourse, in this sense? I will say that they do, but again - so do most new political contenders, and not so few of the old ones that have been in opposition for some time. So the relevant question is whether the

2. The "operational heart of extremism," to follow Lipset and Raab's argument $(1970,6)$, "is the repression of difference and dissent, the closing down of the marketplace of ideas. More precisely, the operational essence of extremism, or monism, is the tendency to treat cleavage and ambivalence as illegitimate." 
radical right-wing parties are particularly populist in their discourse? This is an empirical question that requires systematic research to be answered properly, but I would say that they are, but only in a specific way. In their discourse they are primarily preoccupied with questions pertaining to national identity and national security - and their 'negative' doubles immigration, multiculturalism, Islamist threat - and they consistently pit 'the people' mainly against elites that they view as responsible for a cultural and political threat against their idealized image of their nation state. Again, the ethnic nationalism of European radical right-wing parties is more important for their discourse and tends to influence the populist elements.

\section{Conclusions}

All three definitional approaches to populism, as reviewed above, have problems with demarcation. Populist parties are said (1) to appeal to the general will of the people, that is, to be popular - but so do most contemporary political parties (they are 'catch-all parties;' see Kirchheimer 1966); (2) to mobilize against elites - but so do most new political contenders; and (3) to be anti-pluralists - but so are all extremist parties. It thus remains unclear why radical right-wing parties should be labelled populists parties. We may add a fourth point: that populists are selective when constructing their conception of 'the people', by excluding important segments of society. But so are (ethnically) nationalist parties. In my view, therefore, we should stop calling the contemporary radical right-wing parties 'populist parties;' not because these parties lack populist elements, but because these are not the most pertinent features of these parties. Still, when describing these parties, populism or populist may be used in a more restrictive way, as a conditional qualifier, in clarifying, for example, that the ethnic nationalism of European radical right-wing parties tend to be populist in contrast to elitist (Cf. Mudde [2007], who distinguishes between populist and non-populist radical right-wing parties).

Why does it matter how we label radical right-wing parties? What would the consequences be, if any, of labelling these parties 'populist parties'? First, there is a correspondence between the concepts and labels used by social scientists and the language used by journalists when reporting and analyzing politics - and this in turn influence the general public. Second, labels are cognitive devises that influence our understanding of the world. Labels are frames that emphasize certain features of a phenomenon and deemphasize others (Benford and Snow 2000; Rydgren 2009) and which, by doing that, guide our diagnostic and prognostic understanding. In this case, the label 'populist parties' may lead many people to focus on factors such as general anti-elitist attitudes and political protest when, diagnostically, trying to understand the electoral support these parties receive - and to 
defocus factors such as nationalist sentiments and anti-immigrant attitudes. The result will be suboptimal understanding of these parties and the electoral systems they are part of.

\section{References}

Arzheimer, Kai. 2017. "Explaining the electoral support of the radical right," in Jens Rydgren, ed. The Oxford Handbook of the Radical Right. Oxford: Oxford University Press. (Forthcoming)

Bar-On, Tamir. 2017. "Nationalism and the radical right," in Jens Rydgren, ed. The Oxford Handbook of the Radical Right. Oxford: Oxford University Press. (Forthcoming)

Benford, Robert D. and Snow, David A. 2000. "Framing processes and social movements: An overview and assessment." Annual Review of Sociology 26: 611-639.

doi: 10.1146/annurev.soc.26.1.611

Berlin, Isaiah, Hofstadter, Richard and MacRae, Donald. 1968. "To define populism." Government and Opposition 3: 137-179. doi: 10.1111/j.1477-7053.1968.tbo1332.x

Bustikova, Lenka. 2017. "The radical right in Eastern Europe," in Jens Rydgren, ed. The Oxford Handbook of the Radical Right. Oxford: Oxford University Press. (Forthcoming)

Canovan, Margaret. 1981. Populism. London: Harcourt Brace.

Canovan, Margaret. 1999. "Trust the people! Populism and the two faces of democracy," Political Studies 42: 2-16. doi: 10.1111/1467-9248.00184

Fryklund, Björn and Tomas Peterson. 1981. Populism och missnöjespartier $i$ Norden. Studier $i$ småborgerlig klassaktivitet. Lund: Arkiv Förlag.

Hawkins, Kirk A. 2009. "Is Chávez populist? Measuring populist discourse in comparative perspective." Comparative Political Studies 42(8): 1040-1067. doi: 10.1177/0010414009331721

Kallis, Aristotle. 2017. "Islamophobia and the radical right," in Jens Rydgren, ed. The Oxford Handbook of the Radical Right. Oxford: Oxford University Press. (Forthcoming)

Kirchheimer, Otto. 1966. "The transformation of the Western European party systems," in Political Parties and Political Development, edited by Joseph LaPalombara and Myron Weiner, 177-200. Princeton: Princeton University Press.

Kriesi, Hanspeter and Pappas, Takis S. eds. 2015. European Populism in the Shadow of the Great Recession. Colchester: ECPR Press.

Lipset, Seymour Martin and Raab, Earl. 1970. The Politics of Unreason: Right-wing Extremism in America, 1790-1970. New York: Harper \& Row.

MacRae, Donald. 1969. -Populism as an ideology," in Populism: Its Meaning and National Characteristics, edited by Ghita Ionescu and Ernest Gellner, 152-165. London: Weidenfeld and Nicolson.

Mény, Yves and Surel, Yves. 2000. Par le peuple, pour le peuple. Le populisme et les démocraties. Paris: Fayard.

Moffitt, Benjamin. 2016. The Global Rise of Populism: Performance, Political Style, and Representation. Stanford, CA: Stanford University Press.

Mudde, Cas. 2007. Populist Radical Right Parties in Europe. Cambridge: Cambridge University Press.

Mudde, Cas and Kaltwasser, Cristóbal R. 2012. "Populism and (liberal) democracy: a framework for analysis," in Populism in Europe and the Americas. Threat or Corrective for Democracy?, edited by Cas Mudde and Cristóbal R. Katwasser, 1-26. 
Mudde, Cas and Katwasser, Cristóbal R. 2017. Populism. A Very Short Introduction. Oxford: Oxford University Press.

Müller, Jan-Werner. 2016. What is Populism? Philadelphia: University of Pennsylvania Press.

Popper, Karl. 1971. The Open Society and Its Enemies. Volume II. The High Tide of Prophecy: Hegel, Marx, and the Aftermath. Princeton, N.J.: Princeton University Press.

Rydgren, Jens. 2003. The Populist Challenge: Political Protest and Ethno-Nationalist Mobilization in France. New York: Berghahn Books.

Rydgren, Jens. 2007. “The sociology of the radical right." Annual Review of Sociology 33: 241262. doi: 10.1146/annurev.soc.33.040406.131752

Rydgren, Jens. 2008. "Immigration Sceptics, Xenophobes, or Racists? Radical right-wing voting in six West European countries.” European Journal of Political Research 47: 737-765.

doi: 10.1111/j.1475-6765.2008.00784.x

Rydgren, Jens. 2009. "Beliefs," in The Oxford Handbook of Analytical Sociology, edited by Peter Hedström and Peter Bearman, 72-93. Oxford: Oxford University Press.

Rydgren, Jens. 2017. “The radical right: An introduction," in Jens Rydgren, ed. 2017. The Oxford Handbook of the Radical Right. Oxford: Oxford University Press. (Forthcoming).

Shils, Edward. A. 1956. The Torment of Secrecy: The Background and Consequences of American Security Policies. London: Heinemann.

Stewart, Angus. 1969. “The social roots,ö in Populism: Its Meaning and National Characteristics, edited by Ghita Ionescu and Ernest Gellner, 180-196. London: Weidenfeld and Nicolson.

Taggart, Paul. 2000. Populism. Buckingham: Open University Press.

Wiles, Peter. 1969. "A syndrome, not a doctrine: Some elementary theses on populism," in Populism: Its Meaning and National Characteristics, edited by Ghita Ionescu and Ernest Gellner, 166-197. London: Weidenfeld and Nicolson.

Worsley, Peter. 1969. “The concept of populism," in Populism: Its Meaning and National Characteristics, edited by Ghita Ionescu and Ernest Gellner, 212-250. London: Weidenfeld and Nicolson.

\section{Author's address}

Jens Rydgren

Department of Sociology

Stockholm University

S-10691 Stockholm

Sweden

jens.rydgren@sociology.su.se

\section{Biographical notes}

Jens Rydgren is Chaired Professor of Sociology at Stockholm University. He is mainly working within the fields of political sociology, ethnic relations, and social networks. His work has appeared in leading journals such as American Journal of Sociology, British Journal of Sociology, European Journal of Political Research, and Social Networks. His latest book is The Oxford Handbook of the Radical Right (edited, Oxford University Press, forthcoming). 


\section{Publication history}

Date received: 27 February 2017

Date accepted: 19 April 2017

Published online: 12 June 2017 